\title{
BreastCare
}

\section{Kursbuch Mammasonographie}

\section{Helmut Madjar}

Stuttgart, Thieme, 2005, 2. Auflage, 280 S., 760 Abb., 129,95 EUR

ISBN 3-13115-242-7

Mit dem Kursbuch Mammasonographie ist ein 254 Seiten langes, reich bebildertes und im A4-Format gedrucktes Buch zur Mammasonographie erschienen. Zum Inhalt dieses Kursbuches gehört auch eine CD.

Das Buch weckt die Erwartung, eine Unterstützung für DEGUM-Kurse zur Mammasonographie, entsprechend der Vorgaben der DEGUM und der KBV zu erhalten. Nach den Inhalten der Kurse ist dieses Buch eingeteilt in die physikalischen und rechtlichen Grundlagen der Mammasonographie, die Untersuchungstechnik, die normale Sonoanatomie und die verschiedenen möglichen Herdbefunde. Erweitert wurde der Bereich der 3D-Sonographie und der Dopplersonographie. Sehr praktisch sind die angehängten Prüfungsfragen zur Mammasonographie, die sich an den Vorgaben der Kurse orientieren.

In der vorliegenden Auflage wurde ein Teil der sonographischen Bilder überarbeitet. Insgesamt entsprechen sie jedoch hinsichtlich ihrer Auflösung nicht mehr ganz den Anforderungen der Jahre 2005/2006. Die laterale Auflösung, die Trennschärfe und die Reduktion von Artefakten ist bei heute zur Verfügung stehenden hochauflösenden Geräten höher. Deshalb entsprechen die Aufnahmen eher den Geräten, die in der Praxis eingesetzt werden. Für die Bildqualität der Doppler- und 3D-sonographischen Bilder gilt gleiches. Dies kann jedoch für den angesprochenen Kursteilnehmer auch von Vorteil sein.

Dieses Buch ist insbesondere für angehende «Mammasonographiker» hilfreich. Die zahlreichen Skizzen und Erläuterungen $\mathrm{zu}$ den Ultraschallbildern erleichtern deren Interpretation und Verständnis. Von besonderem Wert ist die Synopsis von Mammographie-Ultraschall, die zahlreichen Phantom-Untersuchungen und der Bezug zu den Kursthemen.

Durch die angehängte $\mathrm{CD}$ mit ihren Fallbeispielen und die hier, dank aktueller Aufnahmen, sehr gute Bildqualität sowie die Synopsis von mammographischen, sonographischen und Präparate-radiographischen Biopsiebildern gewinnt das Kursbuch zusätzlich an didaktischem Wert. Histologische und zytologische Bilder wären hier noch das «Tüpfelchen auf dem i». Insgesamt ist für Teilnehmer der Mammasonographiekurse dieses Buch als begleitendes Lehrbuch unbedingt zu empfehlen.

\section{Biomarkers in Breast Cancer: Molecular Diagnostics for Predicting and Monitoring Therapeutic Effect}

Giampietro Gasparini, Daniel F. Hayes (eds.)

Totowa, NJ, Humana Press, 2005, 360 p., 155,- USD

ISBN 1-58829-227-4

Prediction of clinically meaningful response to chemotherapy regimens or drugs remains a persistent challenge. In the book series 'Cancer Drug Discovery and Development' Gasparini and Hayes edited the volume with the timeless topic of biomarkers in breast cancer. In the first chapters different methods for study design and validation of new biomarkers with the focus on immunohistochemical application and subsequently tissue microarray preparation are presented. The area of expression profiling and comparison of detection methods for gene amplification exemplified by HER-2/neu detection are also among the technical and general introductory topics. Two main parts of the book present the results concerning tissue predictive tumor markers and the detection of early tumor cell dissemination. The different parts are well written and comprehensible also for readers not engaged in the field.

However, the blurb of the book is a little misleading because the evaluation of HER2, EGFR family members, p53 and UPA/PAI-1 are not only the highlights but the sole biomarkers evaluated in detail. As estrogen receptor (ER), progesterone receptor (PgR), Her-2/neu, epidermal growth factor receptor (EGF-R), p53 and bcl-2 (not discussed in the book) are well-known markers, unfortunately the book offers nothing new in this respect to readers working in the field. According to the long production process this book seemingly needed, the listed references for each chapter are almost two years old. Especially in fields with fast-evolving knowledge due to the application of new techniques which are also presented in the book and discussed in the future directions section, the content of the book is behind the common knowledge at the day of printing. However, this is a problem every book has to face.

The book is addressed to laboratory investigators developing new tumor markers, clinical investigators testing them, and clinicians using them. As the chapters are written in a review style the book provides a state-ofthe-art overview at least until 2004 for readers seeking a general idea of the progress in the field of biomarkers in breast cancer and for those entering the field.

Norbert Arnold, Kiel 